\title{
Reconstructing the Tropical Storm Ketsana flood event in Marikina River, Philippines
}

\author{
C. C. Abon, C. P. C. David, and N. E. B. Pellejera \\ National Institute of Geological Sciences, University of the Philippines Diliman, Quezon City, Philippines
}

Received: 1 July 2010 - Published in Hydrol. Earth Syst. Sci. Discuss.: 25 August 2010

Revised: 25 February 2011 - Accepted: 10 March 2011 - Published: 26 April 2011

\begin{abstract}
In September 2009, Tropical Storm Ketsana (local name: TS Ondoy) hit the Manila metropolitan area (Metro Manila) and brought an anomalous volume of rain that exceeded the Philippines' forty-year meteorological record. The storm caused exceptionally high and extensive flooding. Part of this study was a survey conducted along the stretch of the Marikina River, one of the major rivers that flooded. Postevent resident interviews were used to reconstruct the flooding in the absence of stream gauge data. Hydraulic and hydrologic modeling were carried out to understand the mechanism that brought the flood. Peak floods occurred at different hours along the river resulting from the transmission of water from the main watershed to the downstream areas. Modeled peak flood and flood timing coincided well with actual observations except for downstream stations where actual peak floods were observed to have occurred at a later time. Compounding factors such as other flood sources and stream backflow could have caused this discrepancy. Nevertheless, prediction of flood heights and the use of the known time lag between the peak rainfall and the peak runoff could be utilized to issue timely flood forecasts to allow people to prepare for future flooding.
\end{abstract}

\section{Introduction}

On 26 September 2009, Tropical Storm Ketsana (local name: Ondoy) hit the Manila metropolitan area (hereafter referred to as Metro Manila) and brought $347.5 \mathrm{~mm}$ rainfall in only six hours, which reached $413 \mathrm{~mm}$ in nine hours and totaled $448.5 \mathrm{~mm}$ after twelve hours. This rainfall amount was the highest in the country's forty-year record and surpassed the typhoons of 1970 and 1976 that brought $403.1 \mathrm{~mm}$ and

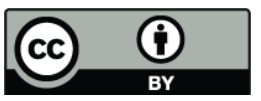

Correspondence to: C. P. C. David (cpdavid@nigs.upd.edu.ph)
$371.6 \mathrm{~mm}$ of rainfall in $24 \mathrm{~h}$, respectively. The volume of rainfall resulted in a flood that was exceptionally high and extensive, making it extremely devastating. An estimated worth of damages to property and infrastructure reached 2 billion pesos (US $\$ 43.5$ billion) and left more than a million Filipinos homeless.

News reports and preliminary assessment of the event pointed out the anthropogenic factors such as clogged canals, illegal settlements, and poor urban planning aggravated the damages. However, a significant factor in the damage brought by the floods can be attributed to the lack of preparedness of the populace. No warning or monitoring systems were in place. With high intensity and short duration rainfall events like Typhoon Ketsana, it is necessary to have an early warning system that can issue rapid flood forecasts. To date, such early warning system does not exist in the Marikina River Basin (hereafter referred to as MRB).

Previous studies by the Mines and Geosciences Bureau (MGB) have produced flood hazard maps that illustrate the whole MRB floodplain to be flood prone with an exceedingly generalized distribution of flooding. These inundation maps fail to include areas adjacent to river channels that experience flash flooding as soon as the capacity of these channels are exceeded, often just a few hours after a rain event has started. The relation of the time of channel breaching to peak rainfall is crucial in the accurate prediction of flooding and issuance of real-time flood forecast and therefore should be the main focus of further efforts.

Improving flood preparedness requires an understanding of the hydrological features of the Ketsana flood, and the development of flood forecasting models that can be deployed in real-time to estimate the likely severity of future flood events. The aim of this study is to develop such a model and evaluate its performance against data from actual flood information.

The Marikina River Basin (MRB) is situated in one of the highly urbanized areas in Metro Manila. Its drainage area

Published by Copernicus Publications on behalf of the European Geosciences Union. 

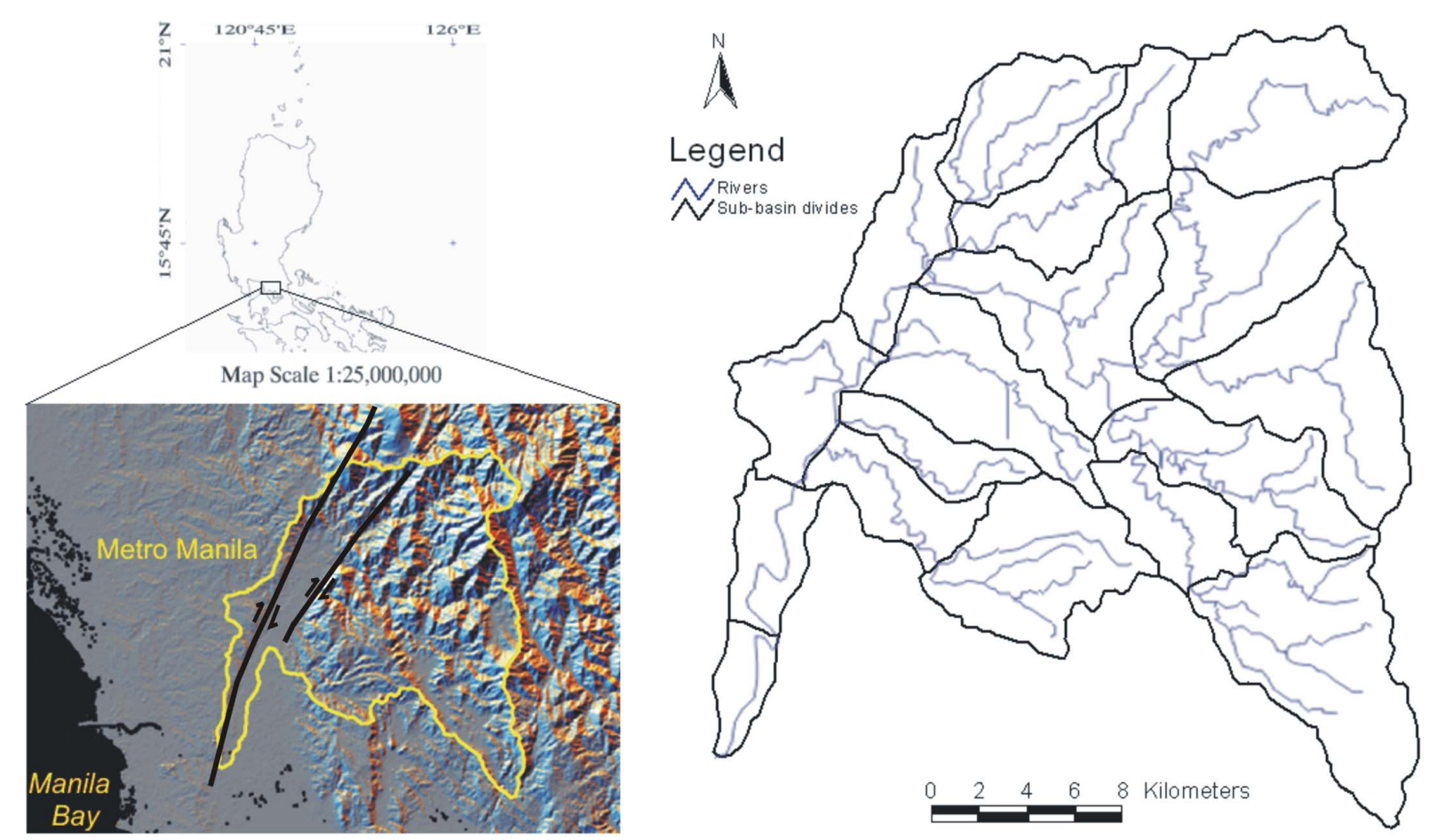

Fig. 1. The Marikina River Basin transverse by the East and West Marikina Valley Faults (black lines).

of $582 \mathrm{~km}^{2}$ starts in the western slopes of the Sierra Madre Mountain Range (Fig. 1). Several rivers, including Montalban, Wawa, Tayabasan, Boso Boso, Manga, and Nangka, feed into the 31-km Marikina River that flows southward. The Marikina River floodplain is in part defined by the Valley Fault System, with the up thrown blocks comprising the high relief areas of Antipolo City to the east and the Diliman Plateau to the west.

The region experiences Type II climate which means having a pronounced wet and dry seasons. November to April is typically the dry while May to October is considered to be the wet season. The average annual rainfall is around $2405 \mathrm{~mm}$ with a monthly maximum of $504.2 \mathrm{~mm}$ usually during August and a minimum of $7.2 \mathrm{~mm}$ every February (PAGASA, 2009).

Geographical Information System (GIS) provides an ideal tool for environmental planning and is a well-established tool used for hydrologic modeling, making use of the capabilities of modern, high-speed computers to store large amounts of environmental data in geographical format and to manipulate these data according to some model of environmental processes, as well as to display material in pictorial form (Bhadra et al., 2009; Coroza et al., 1997). GIS helps redefine the model in spatial context by giving new possibilities in understanding the fundamental physical processes underlying the hydrological cycle and the solution of mathematical equations representing those processes (Castrogiovanni et al., 2005; Liu and De Smedt, 2005; Correla et al., 1998; Coroza et al., 1997). The results can be presented visually, which is exceptionally useful for non-technical people and to disaster managers (Usul and Burak, 2006; Wolski et al., 2006; Zerger and Wealands, 2004; Chubey and Hathout, 2004). Moreover, the availability of free digital elevation models (DEMs) such as those from Shuttle Radar Topography Mission (SRTM) provide important input data in hydrologic and hydraulic modeling, especially when finances are a limitation. Several studies have confirmed that the overall quality of SRTM DEM is sufficient for hydrologic model applications and flood risk analysis (Schumann et al., 2008; Demirkesen et al., 2007; Ludwig and Schneider, 2006; Valeriano et al., 2006).

\section{Methodology}

\subsection{Flood reconstruction}

In the absence of any river gauging data along the river, local residents living along the Marikina River were interviewed two days after the Ketsana flood event. The residents were asked to report the time of peak flood, as well as the estimated maximum height and rate of flood water increase. This is primarily to reconstruct the flood and determine the lag time between the peak rainfall and peak run-off, as well as flood wave velocity. At least five respondents from eight stations were included in the survey. The stations chosen include areas from the upstream of Marikina River to its downstream areas: Sitio Harangan, Wawa, San Isidro, Pacific 


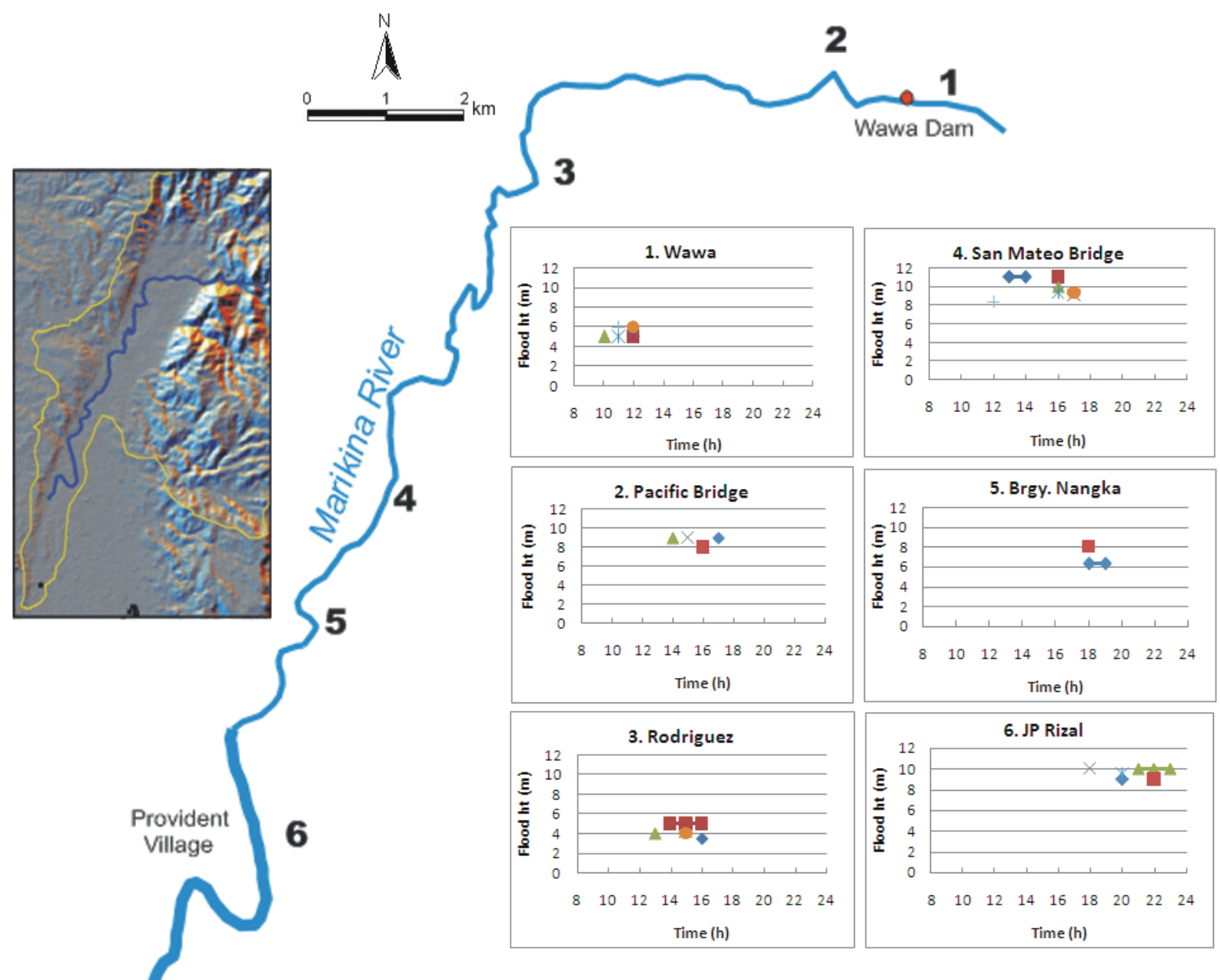

Fig. 2. Anecdotal accounts of the time of peak flooding in various points along the Marikina River.

Bridge, Rodriguez, San Mateo Bridge, Brgy. Nangka, and JP Rizal. Flood marks in houses, bridges and trees were also noted and measured with respect to the ground level (Fig. 2).

\subsection{Basin delineation}

A finished 3-arc second (90 m resolution) SRTM DEM was processed in an open access GIS platform-Integrated Land and Water Information System (ILWIS version 3.2) to delineate the basin and the sub-basins of the area for the hydrologic modeling. The ILWIS's DEM hydro-processing component included DEM visualization, flow determination, flow accumulation, and drainage network extraction. Once the drainage network was extracted, a drainage network ordering was performed. Finally, basin delineation was performed using the output map of drainage network ordering operation and flow direction operation.

More than 400 small sub-basins were delineated in ILWIS. This number of sub-basin components would be a cumbersome task to model and unnecessary for the basin model that we developed. Adjustments therefore were done using
Arcview (ESRI), which is likewise a GIS platform. The shp files from ILWIS were exported to Arcview and associated small basins were merged. A total of 18 sub-basins were finally delineated and were used for the basin model development.

\subsection{Hydrologic modeling: HEC-HMS}

The hydrologic modeling method was employed to generate peak flows and hydrographs for different areas along the Marikina River for TS Ketsana. With this, the amount of lag time between the peak rainfall and peak run-off could be determined, as well as the timing of peak run-off of different points along the stretch of the Marikina river. The Hydrologic Engineering Center's Hydrologic Modeling System (HEC-HMS), version 3.2 developed by the US Army Corps of Engineers, was used to develop the hydrologic model (HEC-HMS, 2008). Inputs included information from the basin model, the meteorological model, time-series data and paired data, and control specifications. 
The sub-basin map previously generated was used as a guide in creating the basin model of the Marikina River Basin. The SCS-CN loss method was employed. This method is one of the most popular and widely used methods in hydrologic modeling and hydrologic forecasting (e.g. van Dijk, 2010; Maharjan et al., 2009; Geetha et al., 2008). In the study of Lastra et al. (2008), they chose the SCS method, for it is commonly used in different environments and delivers good results. Its calculation is easier because it requires only few variables, and despite its simplicity, it gives results as good as the more complex models. In the study of Baltas et al. (2007), they used the SCS-CN method to determine the initial abstraction ratio in a watershed using various rainfall events. This method also works well on rainfall-runoff data of high magnitude (Mishra et al., 2005).

The SCS-CN method calculates precipitation excess as a function of cumulative precipitation, land use, soil cover, and antecedent moisture given by the equation (SCS, 1972):

$P_{\mathrm{e}}=\frac{\left(P-I_{\mathrm{a}}\right)^{2}}{P-I_{\mathrm{a}}+S}$

where, $P_{\mathrm{e}}=$ accumulated excess rainfall or direct runoff, $P=$ accumulated amount of rainfall, $I_{\mathrm{a}}=$ amount of initial abstraction, and $S=$ storage or the potential maximum retention of the watershed. According to analysis of the results of the numerous experiments, the SCS developed an empirical relationship between $I_{\mathrm{a}}$ and $S$ as $I_{\mathrm{a}}=0.2 S$. The cumulative excess at time $t$ was thus given as:

$P_{\mathrm{e}}=\frac{(P-0.2 S)^{2}}{P_{\mathrm{a}}+0.8 S}$

The SCS Unit hydrograph (SCS UH) was used to transform rainfall excess into direct surface run-off. This method was appropriate for determining the timing of the rainfall excess with respect to the peak of the direct run-off. The UH peak $\left(U_{\mathrm{p}}\right)$ and time of $\mathrm{UH}$ peak $\left(T_{\mathrm{p}}\right)$ are given as:

$U_{\mathrm{p}}=C \frac{A}{T_{\mathrm{p}}}$

where, $A=$ watershed area; and $C=$ conversion constant (2.08 in SI). The time of peak is related to the duration of the unit excess precipitation as:

$T_{\mathrm{p}}=\frac{\Delta t}{2}+t_{\mathrm{lag}}$

where $\Delta t=$ the excess precipitation duration and $t_{\mathrm{lag}}=$ the basin lag or the time difference between the center of mass of rainfall excess and the peak of the direct run-off.

The land-use classification map was derived from existing satellite imagery. The empirical equation from SCS-CN was used to calculate for the Curve Number of each sub-basin. The Type II Antecedent Moisture Classes (AMC) was chosen, as Type II AMC is applied for normal conditions (Type I is for dry and Type III is for wet). This was the appropriate choice for the typhoon that happened during the month
Table 1. Hydrologic element parameters

\begin{tabular}{lcc}
\hline Sub-basin & Minimum & Maximum \\
\hline Area $\left(\mathrm{km}^{2}\right)$ & 11 & 30.25 \\
Curve Number $(\mathrm{CN})$ & 65 & 90 \\
Time of Concentration $(\mathrm{h})$ & 2.3 & 5.8 \\
\hline
\end{tabular}

of September in 2009. The soil component in the Marikina River Basin is 50\% Group B (shallow loess, sandy loam) and $50 \%$ Group C (clay loams, shallow sandy loam, soils low in organic content, and soils usually high in clay). The parameters for the hydrologic model are given in Table 1.

\section{Results and discussion}

\subsection{Interviews and fieldwork}

Data on flood height and peak flood timing for each station as gathered from key informants were within reasonable error, confirming the usefulness of first-hand account of flood characteristics. The interviews revealed that the time of peak flooding along the Marikina River varied significantly (Fig. 3). The highest intensity rain recorded in Metro Manila started around 09:00 to 12:00 LT (local time) but may have occurred an hour or so earlier in the Montalban Mountains in the northeast. The recorded floods in the most upstream station started at 10:00 LT, while the highest floods downstream were recorded between 20:00 to 22:00 LT. This means that the lag time between rainfall and flooding was anywhere from $1-10 \mathrm{~h}$. The peak flood heights based on descriptive accounts ranged from one meter up to $12 \mathrm{~m}$ with respect to the riverbed. The highest flood heights were recorded in San Mateo Bridge and JP Rizal stations.

The accuracy of the collected interview data gives potential merit to this methodology to reconstruct flood events. Undertaking interviews following flood events in gauged basins and evaluating physical measures against the perception of respondents would allow the design and development of future interview-based flood reconstruction.

\subsection{Basin and sub-basin delineation using GIS}

The outputs of basin delineation are various maps necessary for the development of the hydrologic model. Figure 4 shows the different maps generated from the DEM hydroprocessing. The river network map of the 18 sub-basins shows a distinctly high drainage density typical of dendritic systems and reflecting a highly dissected basin. Small basins will respond faster to rainfall input and will likely have a faster hydrologic response compared to a single large basin. 


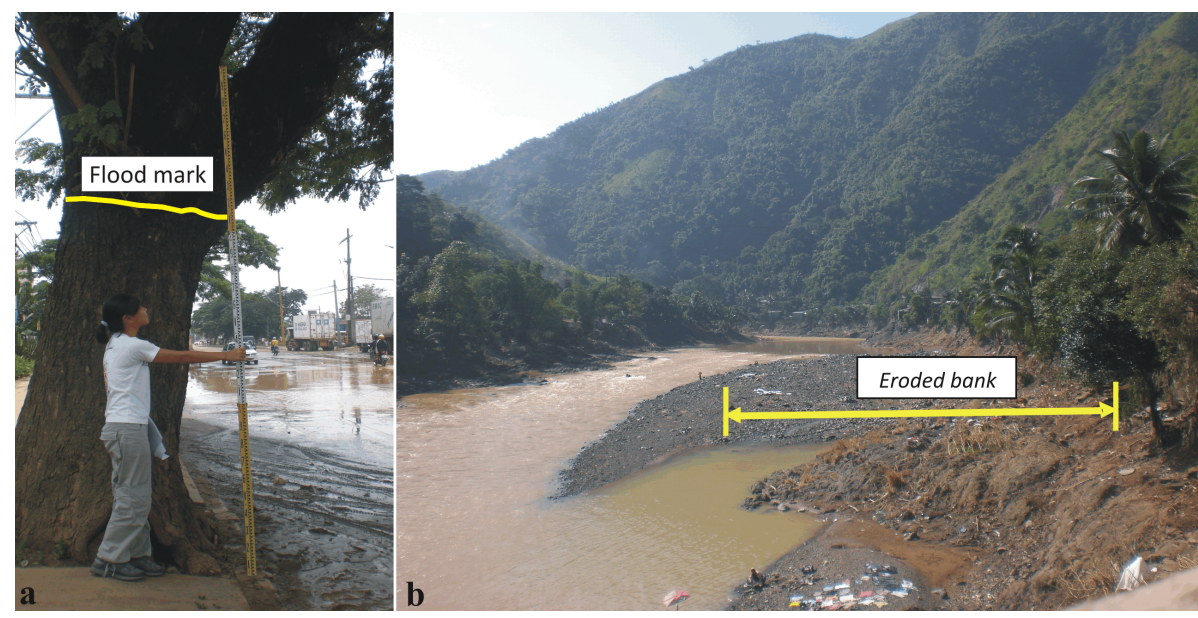

Fig. 3. (a) Photo taken along JP Rizal Avenue showing mud (stain) deposits on the bark of the tree indicating flood height and; (b) photo of upstream Marikina River showing extensive bank erosion.
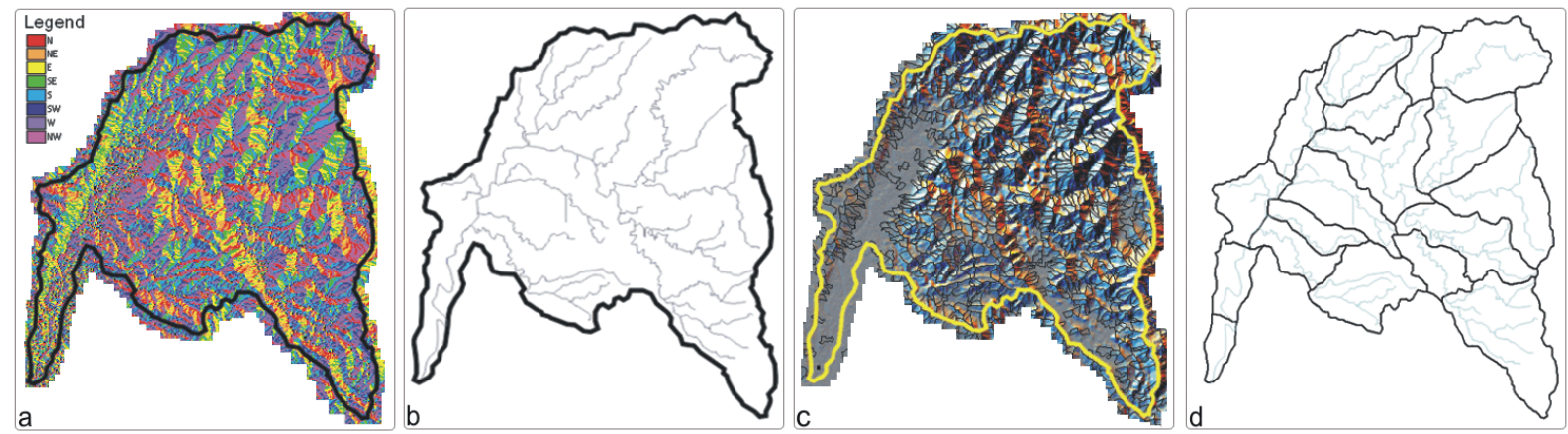

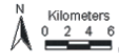

Fig. 4. Maps generated from DEM-Hydroprocessing (a) flow direction map, (b) drainage network map, (c) sub-basin map, and (d) merged sub-basin map.

\subsection{Hydrologic modeling: HEC-HMS}

The rainfall data used were the records of Philippine Atmospheric Geophysical and Seismological Administration (PAGASA), Science Garden Quezon City which is southwest of the study area. Considering that the tropical cyclone moved from east to west, it should be noted that rainfall occurred slightly earlier $(\sim 1.5 \mathrm{~h})$ in the watershed compared to where the weather station is located. Figure 5 shows the results of the discharge simulation run in HEC-HMS. As expected, the arrival of peak discharge varied in six stations as to what was gathered from the interviews. In Station 1, the calculated peak discharge is $2197 \mathrm{~m}^{3} / \mathrm{s}$ and arrived at around 12:30 LT; $2197.5 \mathrm{~m}^{3} \mathrm{~s}^{-1}$ at 13:00 LT in Station $2 ; 3771.8 \mathrm{~m}^{3} \mathrm{~s}^{-1}$ at $13: 30 \mathrm{LT}$ in Station $3 ; 4666 \mathrm{~m}^{3} \mathrm{~s}^{-1}$ at 14:00 LT in Station $4,5598.8 \mathrm{~m}^{3} \mathrm{~s}^{-1}$ at $14: 10 \mathrm{LT}$ in Station 5; and $5921.6 \mathrm{~m}^{3} \mathrm{~s}^{-1}$ at 15:00 in Station 6. The peak discharge $5921 \mathrm{~m}^{3} \mathrm{~s}^{-1}$ surpasses the highest in the forty-year record of peak discharges in MRB (Table 2). The lag time between the peak rainfall and runoff range in the upstream stations coincided well with the interview data. The discrepancy in peak runoff in downstream MRB between observed (interview data) and model results are likely due to the other sources of flood waters which were not taken into account in the model. These sources include smaller basins to the east of the river (Nangka River), the storm drain system leading to the Marikina River not necessarily part of the delineated watershed, as well as backflow from downstream Marikina River. The observed peak floods (20:00 LT) in the downstream floodplains is considered as inundation or flood water accumulation from various sources mentioned.

The maximum discharge calculated from the HMS model is $5921 \mathrm{~m}^{3} \mathrm{~s}^{-1}$, which is comparable to the preliminary computations done by the National Hydraulics Research Center (NHRC) (Tabios, 2009), recorded as $5770 \mathrm{~m}^{3} \mathrm{~s}^{-1}$ peak discharge at the Sto. Niño station using a different hydrologic model. The hydrologic modeling results were also compared to a discharge rating curve from a Department of Public 
$*$
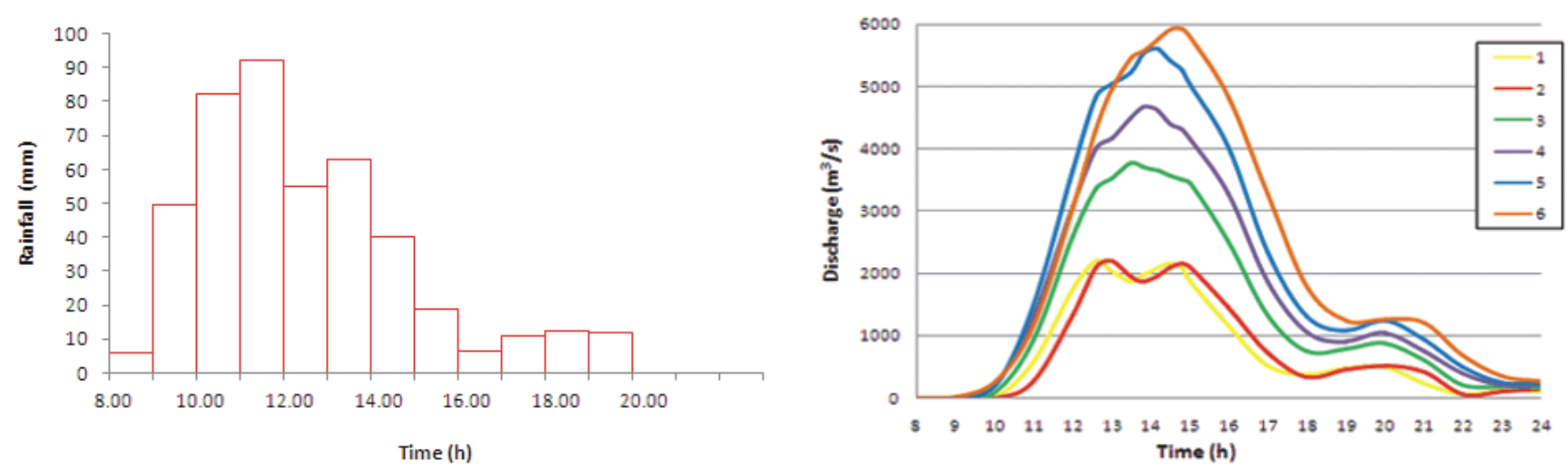

Fig. 5. The rainfall data used in the hydrologic model simulation and the resultant hydrographs. The different colors represent the corresponding station as the interview stations.

Table 2. Ten highest discharges in Marikina.

\begin{tabular}{lc}
\hline Year & Maximum Discharge $\left(\mathrm{m}^{3} / \mathrm{s}\right)$ \\
\hline 1986 & 2650 \\
1970 & 2464 \\
1959 & 2072 \\
1977 & 2051 \\
1966 & 2036 \\
2000 & 1895 \\
1998 & 1680 \\
1995 & 1676 \\
1999 & 1642 \\
1967 & 1609 \\
\hline
\end{tabular}

Works and Highway survey (DPWH-JICA, 2003) given as: $Q=17.01(H-0.00)^{1.85}$ for $H<5.33 \mathrm{~m}$ and $Q=0.20(H-$ $0.00)^{4.49}$ for $H>5.33 \mathrm{~m}$. The peak flow of $5921.6 \mathrm{~m}^{3} \mathrm{~s}^{-1}$ computed from the HEC-HMS corresponded to the gage height of $H=9.9 \mathrm{~m}$ which is comparable to what was computed and observed by local residents.

\section{Conclusions and recommendations}

In the absence of gauging stations data for hydrologic modeling, interviews and flood markers showed to be potentially helpful in reconstructing flood events. Anecdotal accounts showed that the time lag between the peak rainfall and peak flood in Marikina River Basin varied with distance from the watershed. The lag time increased downstream from $2 \mathrm{~h}$ in Station 1 (Brgy Wawa) to up to $10 \mathrm{~h}$ in Station 6 (JP Rizal). These were consistent with the results of the built hydrologic model and previous studies, except in the downstream stations where more factors come into play. Nevertheless, the lag time observed between rainfall and flooding would have been enough to warn the communities to prepare for the impending floods.

The model developed in this study can be further refined with actual data and integrated into early warning systems. As for any flood model, a good set of precipitation data is required. Six telemetered rain gauges have now been installed in the watershed since the Ketsana flood. The next step would be to directly feed rain data into a flood model which can estimate real-time flood height and timing. This will then serve as a basis for the community early warning system. Future studies should also include mapping of the extent of flood inundation to determine how this amount of discharge translates into flood spatial extent and distribution. The results of this study can be used to generate flood risk maps when integrated with channel model and digital elevation data with sufficient resolution.

Compounding factors such as clogged urban storm drains and stream constrictions due to informal settlements may have contributed to the flooding. However, the model suggests that in extreme rainfall events, the sheer amount of rainfall in the watershed will result in the expected floods. Still, the effect of these other factors should be quantified to verify the degree of their impact to the flood event. This can be done by setting-up a more sophisticated hydrologic model taking into account storm drains (treated as tributaries) and riverbank settlement areas by increasing model coefficients (i.e. surface roughness).

Many urban centers like Metro Manila are located in floodplains and will be constantly affected during times of high precipitation events. It is therefore imperative to install hazard mitigation programs to lessen the effects of flooding. As shown in this study, enough lag time between upstream and downstream floods is usually present, such that flood preparation is possible. Lastly, predicting flood heights through modeling can be done with meager resources and therefore making such efforts easier to replicate in other parts of the country facing a similar predicament. 
Acknowledgements. This research was undertaken and funded by the Environment Monitoring Lab, National Institute of Geological Sciences. Gratitude is also extended to DOST-PAGASA for the rainfall data.

Edited by: S. Thompson

\section{References}

Baltas, E. A., Dervos, N. A., and Mimikou, M. A.: Technical Note: Determination of the SCS initial abstraction ratio in an experimental watershed in Greece, Hydrol. Earth Syst. Sci., 11, 18251829, doi:10.5194/hess-11-1825-2007, 2007.

Bhadra, A., Bandyopadhyay, A., Singh, R., and Raghuwanshi, N. S.: Rainfall-Runoff Modeling: Comparison of Two Approaches with Different Data Requirements, Water Resour. Manage., 24(1), 37-62, doi:10.1007/s11269-009-9436-z, 2009.

Castrogiovanni, E. M., La Loggia, G., and Noto, L. V.: Design storm prediction and hydrologic modeling using a web-GIS approach on a free-software platform, Atmos. Res., 77, 367-377, 2005.

Chubey, M. S. and Hathout, S.: Integration of RADARSAT and GIS modeling for estimating Red River flood risk, Geojournal, 59, 237-246, 2004.

Coroza, O., Evans, D., and Bishop, I.: Enhancing runoff modeling with GIS, Landscape Urban Plan., 38, 13-23, 1997.

Correla, F. N., Rego, F. C., Saraiva, M., and Ramos, I.: Coupling GIS with Hydrologic and Hydraulic Flood Modelling, Water Resour. Manage., 12, 229-249, 1998.

Demirkesen, A. C., Evrendilek, F., Berberoglu, S., and Kilic, S.: Coastal Flood Risk Analysis Using Landsat-7 ETM+ Imagery and SRTM DEM: A Case Study of Izmir, Turkey, Environ. Monitor. Assess., 131, 293-300, 2007.

DPWH-JICA - Department of Public Works and Highways-Japan International Cooperation Agency: Manual on Flood Control Planning, 2003.

Geetha, K., Mishra, S. K., Eldho, T. I., Rastogi, A. K., and Pandey, R. P.: SCS-CN-based Continuous Simulation Model for Hydrologic Forecasting, Water Resour. Manage., 22, 165-190, doi:10.1007/s11269-006-9149-5, 2008.

HEC-HMS - Hydrologic Modeling System: Technical Reference Manual, US Army Corps of Engineers Hydrologic Engineering Center, Davis, CA, 2008.

Lastra, J., Fernandez, E., Diez-Herrero, A., and Marqueinez, J.: Flood Hazard Delineation combining geomorphological and hydrological methods: an example in the Northern Iberian Peninsula, Nat. Hazards, 45, 277-293, 2008.
Liu, Y. B. and De Smedt, F.: Flood Modeling for Complex Terrain Using GIS and Remote Sensed Information, Water Resour. Manage., 19, 605-624, 2005.

Ludwig, R. and Schneider, P.: Validation of digital elevation models from SRTM X-SAR for applications in hydrologic modeling, ISPRS J. Photogramm. Remote, 60, 339-358, 2006.

Maharjan, M., Pathirana, A., Gersonius, B., and Vairavamoorthy, K.: Staged cost optimization of urban storm drainage systems based on hydraulic performance in a changing environment, Hydrol. Earth Syst. Sci., 13, 481-489, doi:10.5194/hess-13-4812009, 2009.

Mishra, S. K., Jain, M. K., Bhunya, P. K., and Singh, V. P.: Field Applicability of the SCS-CN-Based Mishra-Singh General Model and its Variants, Water Resour. Manage., 19, 37-62, 2005.

PAGASA - Philippine Atmospheric Geophysical and Seismological Administration: http://kidlat.pagasa.dost.gov.ph/ (last access: 23 November 2007), 2009.

Schumann G., Matgen P., Cutler M.E.J., Black A., Hoffmann L., Pfister L., 2008 Comparison of remotely sensed water stages from LiDAR, topographic contours and SRTM, ISPRS Journal of Photogrammetry and Remote Sensing 63, 283-296

SCS - Soil Conservation Service: National Engineering Handbook, section 4, Hydrology, US Department of Agriculture, US Government Printing Office, Washington, DC, 1972.

Tabios III, G. Q.: Marikina River flood hydraulic simulation during typhoon Ondoy of 26 September 2009, National Hydraulics Research Center Public Presentation, University fo the Philippines, Diliman, 2 October, 2009.

Usul, N. and Burak, T.: Flood forecasting and analysis within the Ulus Basin, Turkey, using geographic information systems, Nat. Hazards, 39, 213-229, 2006.

Valeriano, M. M., Kuplich, T. M., Storino, M., Amaral, B. D., Mendes, J. N., and Lima, D. J.: Modeling small watersheds in Brazilian Amazonia with shuttle radar topographic mission-90 m data, Comput. Geosci., 32, 1169-1181, 2006.

van Dijk, A. I. J. M.: Selection of an appropriately simple storm runoff model, Hydrol. Earth Syst. Sci., 14, 447-458, doi:10.5194/hess-14-447-2010, 2010.

Wolski, P., Savenije, H. H. G., Murray-Hudson, M., and Gumbricht, T.: Modelling of the flooding in the Okavango Delta, Botswana, using a hybrid reservoir-GIS model, J. Hydrol., 331, 58-72, 2006.

Zerger, A. and Wealands, S.: Beyond Modelling: Linking Models with GIS for Flood Risk Management, Nat. Hazards, 33, 191208, 2004. 